Jurnal Cendekia Akuntansi

pISSN

Volume 1, Nomor 1

eISSN

Kediri, Juni 2020

\title{
ANALISIS KINERJA BERDASARKAN METODE BALANCED SCORECARD (STUDI KASUS PADA KANTOR PERPUSTAKAAN DAN ARSIP KABUPATEN LUMAJANG)
}

\author{
Isnan Murdiansyah $^{1}$ \\ Nanik Wahyuni ${ }^{2}$ \\ Yona Octiani Lestari ${ }^{3}$ \\ ${ }^{1}$ UIN Maulana Malik Ibrahim Malang \\ ${ }^{2}$ UIN Maulana Malik Ibrahim Malang \\ ${ }^{3}$ UIN Maulana Malik Ibrahim Malang
}

\begin{abstract}
Abstrak
Penelitian ini bertujuan untuk mengetahui implementasi balanced scorecard untuk mengukur kinerja Kantor Perpustakaan dan Arsip Kabupaten Lumajang. Penelitian menggunakan deksriptif kualitatif. Penelitian difokuskan pada pengukuran kinerja organisasi sektor publik dengan menggunakan analisis balanced scorecard dengan menggunakan empat perspektif pengukuran, yaitu perspektif keuangan, perspektif proses internal, dan perspektif pembelajaran dan pertumbuhan. Hasil penelitian menunjukkan secara keseluruhan kinerja Kantor Perpustakaan dan Arsip Kab. Lumajang dapat dikatakan baik mengunakan pengukuran balanced scorecard.

Kata kunci: balanced scorecard, perspektif keuangan, perspektif proses internal, perspektif pembelajaran dan perspektif pertumbuhan.
\end{abstract}

\section{PENDAHULUAN}

Perkembangan organisasi sektor publik di Indonesia masih tertinggal jauh jika dibanding dengan sektor swasta. Undang-Undang No. 22 Tahun 2004 tentang Pemerintah Daerah dan Undang-Undang No.25 tentang Perimbangan Keuangan Pemerintah Pusat dan Daerah menjadi tonggak dimulainya Otonomi Daerah. Otonomi daerah merupakan upaya pemberdayaan daerah dalam pengambilan 
keputusan daerah secara lebih leluasa untuk mengelola sumber daya yang dimiliki sesuai dengan kepentingan, prioritas dan potensi daerah sendiri sehingga diharapkan setiap daerah mampu mengelola dan memanfaatkan potensinya masing-masing yang ada di daerah tersebut.

Organisasi sektor publik mendapatkan dan memanfaatkan pendanaan yang bersumber dari pemerintah yang biasanya dianggarkan oleh pemerintah baik melalui APBN ataupun APBD serta memiliki fungsi untuk memberikan pelayanan kepada masyarakat. Secara mendasar, organisasi sektor publik sangat berbeda dengan organisasi swasta. Tujuan utama dari perusahaan swasta/bisnis adalah pencapaian maksimum profit dan mengeksploitasi sumber daya secara maksimal, sedangkan organisasi sektor publik berfungsi untuk memberikan pelayanan publik dan mendistribusikan kesejahteraan dalam berbagai konteks target sosial dan ekonomi.

Pengukuran kinerja organisasi sektor publik dilaksanakan untuk dapat membantu memperbaiki kinerja pemerintah dan membantu pemerintah berfokus pada tujuan dan sasaran unit program kerja sehingga dapat meningkatkan efektivitas dan efisiensi organisasi sektor publik dalam hal memberikan pelayanan publik. Selain itu, pengukuran kinerja sektor publik dimaksudkan untuk mewujudkan pertanggungjawaban publik dengan memperbaiki komunikasi kelembagaan. Informasi yang digunakan untuk pengukuran kinerja sektor publik dapat menggunakan informasi financial dan non financial.

Kantor Perpustakaan dan Arsip merupakan salah satu organisasi sektor publik yang berhubungan dengan tata kelola pendidikan dan peningkatan kualitas sumber daya manusia, khususnya dalam peningkatan budaya membaca dalam suatu daerah. Hubungan yang dinamis dan saling mendukung antara pemerintah daerah melalui Kantor Perpustakaan Arsip dengan masyarakat serta pihak lain yang terkait akan mampu menciptakan iklim pendidikan, khususnya membaca yang dinamis dan kondusif dalam suatu wilayah.

Seringkali peningkatan budaya membaca dalam suatu daerah tidak berjalan sebagaimana yang diharapkan lantaran masalah yang dihadapi, seperti: kurangnya fasilitas perpustakaan daerah, berkurangnya minat generasi muda dalam membaca, dan kurangnya sosialisasi kampanye pentingnya membaca dari pemerintah daerah setempat. Untuk itu, Pemerintah Daerah (Kantor Perpustakaan dan Arsip) sebagai regulator harus mampu menciptakan iklim budaya membaca dan pembangunan pendidikan yang sehat dan bergairah melalui berbagai perangkat (kebijakan dan peraturan) yang dimilikinya.

Kantor Perpustakaan dan Arsip diharapkan mampu menjadi salah satu tulang punggung pemimpin penggerak pendidikan nasional demi membangkitkan daya saing sumber daya. Oleh sebab itu, peran Kantor Perpustakaan dan Arsip pada saat ini menjadi sangat penting. Selain harus dapat merumuskan peraturan dan kebijakan yang mampu mengakomodasi kepentingan para pelaku pendidikan, baik sekolah, guru, siswa dan pihak lainnya. Kantor Perpustakaan dan Arsip juga dituntut mampu menciptakan suasana yang kondusif demi menjaga keberlangsungan tumbuhnya pendidikan nasional berbasis budaya membaca. Oleh sebab itu, dibutuhkan suatu kinerja yang optimal dari Kantor Perpustakaan dan Arsip baik sebagai organisasi maupun regulator. 
Salah satu alat pengukuran kinerja yang dapat digunakan dalam organisasi sektor publik adalah balanced scorecard. Analisis balanced scorecard bertitik tolak pada keseimbangan antara ukuran keuangan dan non-keuangan dengan menggunakan empat perspektif, yaitu perspektif keuangan, perspektif pelanggan, perspektif proses internal, dan perspektif pembelajaran dan pertumbuhan.

Beberapa hal yang membuat balanced scorecard lebih unggul dari metode lainnya adalah: (1) pengukuran yang lebih holistic, luas, dan menyeluruh (komprehensif) berdampak bagi organisasi untuk lebih bijak dalam memilih strategis dan membuat organisasi mampu untuk memasuki lingkungan yang kompleks, (2) koherensi setiap perspektif dapat membantu pencapaian sasaran strategis organisasi karena semua sasaran strategis organisasi harus bisa dijelaskan, (3) keseimbangan sasaran strategis yang dihasilkan dalam empat perspektif meliputi jangka pendek dan panjang yang berfokus pada faktor internal dan eksternal, dan (4) setiap perspektif balanced scorecard dapat diukur, sasaran strategis yang sulit diukur seperti, pada perspektif pelanggan (customer), proses bisnis internal, serta pembelajaran dan pertumbuhan dengan menggunakan balanced scorecard dapat dikelola sehingga dapat diwujudkan.

Dilatarbelakangi hal tersebut maka peneliti tertarik untuk mengadakan penelitian di Kantor Perpustakaan dan Arsip sebagai organisasi sektor publik dalam peningkatan kinerja organisasinya. Oleh karena itu, peneliti mengangkat judul dalam penelitian ini adalah: "ANALISIS KINERJA BERDASARKAN METODE BALANCED SCORECARD (STUDI KASUS PADA KANTOR PERPUSTAKAAN DAN ARSIP KABUPATEN LUMAJANG)"

\section{TINJAUAN PUSTAKA}

\section{Implementasi Balanced Scorecard Pada Sektor Publik}

Bagi suatu organisasi pemerintahan, sebagai suatu organisasi sosial non profit seringkali misi organisasinya dirumuskan sebagai organisasi yang berusaha meningkatkan kesejahteraan masyarakat. Oleh karena itu semua strategi, kebijakan, dan program kerja harus disusun dalam rangka meningkatkan kesejahteraan masyarakat.

Pengukuran kinerja pada organisasi sektor publik khususnya pemerintah, terletak pada efisiensi dan efektivitas penggunaan sumber dana yang ada. Dari perspektif finansial, pengukuran kinerja organisasi pemerintahan tidak dapat dipandang dari hasil investasi seperti pada organisasi bisnis sebab organisasi pemerintahan tidak berorientasi pada profit. Dan karena tugas dari organisasi sektor publik adalah untuk menyediakan layanan publik dan mendistribusikan kesejahteraan dalam beberapa konteks target sosial dan ekonomi, cara memperlakukan pendapatan dan biaya sangat berbeda. Pendapatan sektor publik didapat dari pajak, retribusi dan sumbangan masyarakat.

\section{RANCANGAN PENELITIAN}

Penelitian adalah suatu kegiatan untuk mencari, mencatat, merumuskan, dan menganalisis sampai menyusun laporannya (Narbuko, 2003:70). Jenis penelitian yang digunakan dalam penelitian ini merupakan penelitian deskriptif. Penelitian ini lebih difokuskan pada pengukuran kinerja organisasi sektor publik dengan 
menggunakan analisis balanced scorecard dengan menggunakan empat perspektif pengukuran, yaitu perspektif keuangan, perspektif proses internal, dan perspektif pembelajaran dan pertumbuhan.

\section{Obyek Penelitian}

Objek penelitian ini adalah Kantor Perpustakaan dan Arsip Kabupaten Lumajang yang terletak di Jalan Alun-alun Barat No.1 Lumajang.

\section{Teknik Pengumpulan Data}

Metode pengumpulan data dalam penelitian ini mencakup:

1. Observasi (observation)

Peneliti melakukan kegiatan pengamatan secara langsung pada objek penelitian untuk mengetahui karakteristik dan gambaran umum dari organisasi sektor publik yang bersangkutan. Observasi (observation) merupakan teknik atau pendekatan untuk mendapatkan data primer dengan cara mengamati langsung objek datanya.

2. Wawancara (interview)

Wawancara (interview) adalah komunikasi dua arah untuk mndapatkan data dari responden. Wawancara dapat berupa wawancara personal (personal interview), wawancara intersep (intersept interview), dan wawancara telepon (telephone interview). Dalam penelitian ini, peneliti merencanakan melakukan kegiatan wawancara dengan Kepala Kantor Perpustakaan dan Arsip Kab. Lumajang sebagai pucuk pimpinan (top management) dan Kepala Bagian dalam struktur organisasi Kantor Perpustakaan dan Arsip Kab. Lumajang tentang visi dan program Kantor Perpustakaan dan Arsip Lumajang.

3. Dokumentasi (documentation)

Yaitu pengumpulan data dengan melakukan pengamatan, pencatatan, menganalisis, dan mengevaluasi secara langsung ataupun tidak langsung data-data dan dokumen terkait yang ada dalam struktur organisasi Kantor Perpustakaan dan Arsip Kabupaten Lumajang.

4. Kuesioner

Yaitu teknik pengumpulan data dengan menyebarkan pertanyaan secara tertulis kepada responden agar responden menjawab pertanyaan yang sesuai. Penyebaran kuesioner dilakukan untuk mendapatkan data tentang kepuasan dan pengharapan pelaku usaha, pedagang, masyarakat (stakeholders) terhadap pelayanan yang diberikan oleh aparat Kantor Perpustakaan dan Arsip Lumajang dan data tentang proses internal di lingkungan Kantor Perpustakaan dan Arsip Lumajang.

\section{Teknik Pengambilan Sampel}

Teknik pengambilan sampel yang digunakan untuk mengetahui kepuasan pelanggan adalah menggunakan teknik purposive sampling (pemilihan sampel bertujuan). Pengambilan sampel bertujuan dilakukan dengan mengambil sampel dari populasi berdasarkan kriteria tertentu (Jogiyanto, 2010:79). Dalam penelitian ini ada dua sampel yang diteliti yaitu:

1. Sampel dari pelanggan untuk perspektif pelanggan 
Dari sejumlah siswa dan guru pemakai fasilitas perpustakaan daerah, peneliti merencanakan mengambil 35 sampel siswa dan guru yang merupakan anggota perpustakaan daerah Lumajang.

2. Sampel dari populasi pegawai tetap untuk perspektif proses internal

Kantor Perpustakaan dan Arsip Lumajang didukung sumber daya manusia (SDM) berjumlah puluhan orang. Dari jumlah tersebut peneliti mengambil sejumlah 15 sampel yang merupakan pegawai tetap dengan derajat pendidikan minimal sarjana (S1).

\section{Teknik Analisis Data}

Analisis data dilakukan setelah data yang diperlukan telah diperoleh secara lengkap kemudahan data tersebut dianalisis secara kualitatif dan kuantitatif.

a. Analisis Kualitatif

Dalam penelitian ini, data yang sudah berhasil terkumpul, akan diteliti, dianalisa secara kualitatif. Peneliti akan mengevaluasi tentang kejadiankejadian berdasarkan data dan fakta yang diteliti.

b. Analisis Kuantitatif

Dalam penelitian yang menggunakan analisis pendekatan balanced scorecard ini, peneliti akan menganalisis secara kuantitatif terhadap data atau laporan Kantor Perpustakaan dan Arsip, yaitu:

- Perspektif keuangan

Pengukuran kinerja organisasi sektor publik dari perspektif keuangan dapat dilihat dari tingkat pencapaian realisasi (efisiensi) atas target anggaran belanja tahun anggaran 2015 yang telah ditetapkan.

Capaian Indikator Kinerja = Realisasi target/Anggaran x 100\%

Selain menilai capaian penyerapan anggaran, dalam perspektif keuangan ini juga dilihat tingkat keefektifan anggaran yang dilihat dari indikator pencapaian target kinerja dengan hasil yang ada di lapangan.

- Perspektif Pelanggan

Dalam penelitian ini yang dimaksud pelanggan adalah pemakai umum jasa kantor perpustakaan dan arsip, guru, siswa dan masyarakat (stakeholders). Untuk mengetahui tingkat kepuasan para stakeholders terhadap pelayanan Kantor Perpustakaan dan Arsip, peneliti menggunakan hasil jawaban dari kuesioner yang disebar kepada pelanggan Kantor Perpustakaan dan Arsip Lumajang.

- Perspektif proses internal

Dalam perspektif ini, dilakukan pengukuran terhadap program-program yang dilakukan oleh Kantor Perpustakaan dan Arsip Kabupaten Lumajang dalam rangka efektivitas kinerja. Efektivitas kinerja diukur dengan mengevaluasi proses internal yang berjalan di lingkungan dinas pertanian selama ini. Data kuesioner yang disebar kepada pegawai dapat dijadikan acuan peneliti dalam menggambarkan kondisi proses internal di lingkungan Kantor Perpustakaan dan Arsip Lumajang. Selain itu efektivitas diukur dengan anggaran belanja daerah dengan total realisasinya.

- Perspektif pembelajaran dan pertumbuhan 
Dalam perspektif ini dilakukan pengukuran kinerja dari kepuasan karyawan Kantor Perpustakaan dan Arsip Kabupaten Lumajang dan jumlah pegawai yang mengikuti pelatihan atau diklat dalam rangka meningkatkan mutu sumber daya manusia di kalangan Kantor Perpustakaan dan Arsip sendiri.

Employee training $=\Sigma$ peserta training/ $\Sigma$ pegawai $\times 100 \%$

Setiap tahunnya, kepala dinas maupun pegawai Kantor Perpustakaan dan Arsip Kabupaten Lumajang mengikuti berbagai pelatihan dan seminar yang diadakan berbagai instansi yang berkaitan dengan kebijakan dan peraturan baru yang dikeluarkan oleh pemerintah pusat.

\section{PEMBAHASAN}

\section{Perspektif Keuangan}

Berdasarkan data tentang realisasi belanja pegawai langsung dan tidak langsung secara umum bagus dan baik, karena nilai realisasinya rata-rata di atas 90\% lebih meskipun ada pos yang nilai realisasinya mengecewakan, yakni: Program peningkatan dan Pengembangan Pengelolaan Keuangan Daerah yang nilai realisasinya hanya $34,64 \%$. Tentu ini menjadi peringatan rapor merah dari instansi bersangkutan oleh karena itu dinas terkait perlu memberikan penjelasan atas apa dibalik rendahnya daya serapan anggaran tersebut. Beberapa pos belanja yang realisasinya jauh di bawah jumlah yang dianggarkan tersebut bisa jadi disebabkan oleh penetapan jumlah anggaran yang terlalu besar tanpa berkaca dari pengalaman terdahulu, atau perhitungannya yang belum akurat. Bila hal ini terus terjadi, akan ada kemungkinan terjadi penggunaan anggaran yang tidak efektif bahkan tindak korupsi yang membahayakan. Sekali lagi dinas terkait perlu memberikan penjelasan seputar peristiwa rendahnya realisasi di beberapa pos belanja tersebut.

Selanjutnya realisasi belanja modal meliputi belanja modal peralatan dan mesin dan belanja modal aset tetap lainnya. Dari realisasi belanja modal, sebesar Rp. 169.345.000,00 merupakan realisasi dari belanja modal peralatan dan mesin $(85,3$ $\%$ dari jumlah yang dianggarkan). Sementara itu, belanja modal aset tetap lainnya realisasinya sebesar Rp 97.787.500,00 (79,53\% dari jumlah yang dianggarkan). Dari laporan dan nilai belanja modal di atas, dapat peneliti simpulkan bahwa realisasi belanja modal masih kurang baik karena dibawah $90 \%$, oleh karena itu ke depan realisasi tersebut masih perlu ditingkatkan lagi dan tak kalah penting adalah penetapan anggaran belanja modal secara lebih akurat lagi dengan pertimbangan faktor-faktor sosial ekonomi yang sedang berkembang sehingga tercapai kinerja dinas terkait yang lebih optimal lagi.

\section{Perspektif Pelanggan}

Dalam pengukuran kinerja Kantor Perpustakaan dan Arsip Kabupaten Lumajang dalam perspektif pelanggan menggunakan kuesioner yang memuat beberapa item pertanyaan. Hasil kuesioner dalam bentuk analisis statsitik deskriptif variabel kepuasan pelanggan menunjukkan mayoritas responden $(48,81 \%)$ mempersepsikan Baik atas pelayanan Kantor Perpustakaandan Arsip yang diberikan selama ini kepada pelanggan. Sementara itu, persepsi responden 
tertinggi berikutnya atas pelayanan Kantor Perpustakaan dan Arsip adalah pada skor Cukup Baik (37,76\%).

Dengan demikian, peneliti dapat simpulkan bahwa pelayanan yang diberikan oleh Kantor Perpustakaan dan Arsip Lumajang terhadap pelanggan untuk saat ini sudah Baik, meskipun demikian, ke depan tingkat pelayanan ini masih perlu untuk ditingkatkan mengingat skor Baik dan Cukup baik masih di bawah 50\% dari persepsi responden. Artinya peluang untuk meningkatkan pelayanan kepada pelanggan masih terbuka lebar. Jangan sampai karena sistem manajemen kinerja yang kurang terkelola dengan baik, menjadikan tingkat pelayanan nantinya justru tambah menurun ke tingkat skor kurang baik atau bahkan tidak baik.

\section{Perspektif Proses Internal}

Untuk mengukur kinerja Kantor Perpustakaan dan Arsip Kabupaten Lumajang dalam perspektif proses internal, peneliti menggunakan kuesioner item pertanyaan. Berdasarkan hasil perhitungan analisis statistik deskriptif atas jawaban responden dari item pertanyaan tersebut di atas diperoleh nilai jawaban responden. Dari ringkasan hasil statistik deskriptif tersebut, dapat disimpulkan bahwa mayoritas responden yang terdiri dari atas 20 sampel dari pegawai Kantor Perpustakaan dan Arsip Kab. Lumajang menyatakan persepsi baik $(38,00 \%)$ atas kinerja Proses internal yang bekerja di internal Kantor Perpustakaan Arsip Kab. Lumajang. Bahkan, persepsi terbesar berikutnya dari responden atas Proses internal Kantor Perpustakaan arsip Kab. Lumajang menyatakan sangat baik $(29,00 \%)$. Berikutnya 20,00\% dari responden memberikan persepsi cukup baik atas kinerja proses internal di lingkungan Kantor Perpustakaan Arsip Kab. Lumajang. Dengan demikian dapat disimpulkan bahwa kinerja Kantor Perpustakaan arsip Kab. Lumajang dari perspektif Proses internal secara rata-rata sudah baik $(38,00 \%)$, dan capaian ini perlu dipertahankan di tahun-tahun mendatang dengan pembenahan dan pengelolaan manajemen kinerja internal yang semakin lebih baik.

Selain metode pengukuran di atas, kinerja Kantor Perpustakaan Arsip Kab. Lumajang juga diukur dengan analisis efektivitas belanja daerah. Efektivitas anggaran diukur dengan cara membandingkan jumlah nominal yang dianggarkan dengan total realisasi yang terjadi. Dengan demikian, anggaran dikatakan efektif bila rasio realisasinya adalah $100 \%$ atau lebih untuk anggaran pendapatan atau $100 \%$ atau mendekati $100 \%$ untuk anggaran belanja. Dari hasil analisis efektivitas anggaran diketahui bahwa realisasi belanja pegawai secara langsung dan tidak langsung sudah melebihi $90 \%$. Catatan diberikan untuk belanja modal yang nilai realisasinya masih $83,15 \%$. Ke depan hal ini harus terus ditingkatkan realisasi anggaran belanja mencapai $100 \%$ agar daya efektivitasnya menjadi lebih baik sehingga tidak terjadi lagi pencapaian target yang rendah.

\section{Perspektif Pembelajaran dan Pertumbuhan}

Pada tahun 2015 terdapat 16 pegawai/staf Kantor Perpustakaan dan Arsip Kab. Lumajang yang mengikuti training atau pelatihan, maka jika dihitung perbandingan pegawai yang mengikuti pelatihan dengan jumlah total pegawai keseluruhan rasionya $42,1 \%$. Idealnya setiap tahun sebanyak lebih dari $50 \%$ pegawai mengikuti pelatihan baik yang diadakan pusat maupun lembaga swadaya 
lain. Karena hal ini berkaitan dengan produktivitas dan motivasi kerja di kalangan pegawai.

Kemudian untuk rasio peningkatan penggunaan teknologi yang ditunjukkan dalam menunjukkan tahun 2015 telah terjadi peningkatan dan penambahan dalam pengadaan teknologi sebanyak 12 buah dibanding tahun 2014 yang hanya 10 buah. Hal ini sangat penting karena teknologi bisa mneingkatkan efisiensi kinerja, selain itu Kantor Perpustakaan dan Arsip Lumajang telah dilengkapu dengan komputer yang menggunakan operating system terbaru serta dilengkapi fasilitas internet wifi disetiap titik ruangan.

Berdasarkan uraian dan penjelasan di atas dapat disimpulkan kinerja kantor perpustakaan dan arsip Kab. Lumajang cukup baik dengan beberapa indikator banyaknya pegawai/staf yang mengikuti pelatihan/training selama tahun 2015 dan meningkatnya penggunaan teknologi dalam rangka meningkatkan efisiensi kinerja.

Dari hasil penelitian dan uraian pembahasan di atas dapat diketahui bahwa kinerja keuangan Kantor Perpustakaan dan Arsip Kab. Lumajang cukup baik, dengan beberapa indikator, anatra lain: realisasi belanja pegawai langsung ratarata di atas $90 \%$ lebih meskipun ada beberapa kekurangan di pos lainnya. Tentu ini menjadi peringatan rapor merah dari instansi bersangkutan oleh karena itu dinas terkait perlu memberikan penjelasan atas apa dibalik rendahnya daya serapan anggaran tersebut. Namun, ada catatan merah dalam pos belanja modal Dari realisasi belanja modal, sebesar Rp. 169.345.000,00 merupakan realisasi dari belanja modal peralatan dan mesin (85,3 \% dari jumlah yang dianggarkan). Sementara itu, belanja modal aset tetap lainnya realisasinya sebesar Rp 97.787.500,00 (79,53\% dari jumlah yang dianggarkan). Dari laporan dan nilai belanja modal di atas, dapat peneliti simpulkan bahwa realisasi belanja modal masih kurang baik karena dibawah $90 \%$, titik inilah yang harus jadi perhatian dinas terkait. Hasil penelitian ini sesuai dengan penelitian Putro (2009) yang menilai kinerja keuangan pada Badan Pertanahan Kota Malang dan Novriansyah (2014) yang meneliti kinerja Rumah Sakit di Bandar Lampung menggunakan balanced scorecard. Peenelitian ini juga mendukung penelitian Fitriya (2012) yang mengukur kinerja keuanan Rumah Sakit Umum di Kab. Kediri menggunakan metode balanced scorecard.

Selanjutnya aspek kinerja pelanggan juga sudah baik, hal ini ditunjukkan dengan hasil analisis deskriptif kuesioner yang menggambarkan mayoritas responden $(48,81 \%)$ mempersepsikan Baik atas pelayanan Kantor Perpustakaan dan Arsip yang diberikan selama ini kepada pelanggan. Dengan demikian, berarti pelayanan yang diberikan oleh Kantor Perpustakaan dan Arsip Lumajang terhadap pelanggan sudah Baik, meskipun demikian, ke depan tingkat pelayanan ini masih perlu untuk ditingkatkan. Penelitian ini aspek kinerja pelangga ini sesuai dan mendukung penelitian Fitriya (2012), Novriansyah (2014), dan Kartinah (2015).

Pengukuran kinerja melalui proses internal juga menunjukkan hasil yang bagus. Hal ini dibuktikan dengan mayoritas responden yang terdiri dari atas 20 sampel dari pegawai Kantor Perpustakaan dan Arsip Kab. Lumajang menyatakan persepsi baik $(38,00 \%)$ atas kinerja Proses internal yang bekerja di internal Kantor Perpustakaan Arsip Kab. Lumajang. Bahkan, persepsi terbesar berikutnya dari 
responden atas Proses internal Kantor Perpustakaan arsip Kab. Lumajang menyatakan sangat baik $(29,00 \%)$. Berikutnya $20,00 \%$ dari responden memberikan persepsi cukup baik atas kinerja proses internal di lingkungan Kantor Perpustakaan Arsip Kab. Lumajang. Selain itu pengukuran dengan analisis efektivitas anggaran belanja baik belanja pegawai dan modal menunjukkan hasil positif dan baik.

Terakhir pengukuran kinerja dengan menggunakan perspektif pertumbuhan dan pembelajaran menunjukkan hasil yang baik dan positif pula ditunjukkan dengan banyaknya pegawai yang mengikuti pelatihan/training selama tahun 2015 yang mencapai $46 \%$ mendekati $50 \%$ dan rasio penggunaan teknologi terus meningkat semula hanya 10 buah menjadi 12 buah.

\section{Kesimpulan}

Berdasarkan hasil penelitian dan uraian pembahasan di atas tentang analisis kinerja menggunakan metode balanced scorecard dalam mengukur kinerja kantor perpustakaan dan arsip dapat disimpulkan baik. Dengan beberapa indikator, antara lain dari perspektif keuangan, yakni nilai realisasi anggaran belanja untuk setiap pos rata-rata mencapai $90 \%$. Kemudian pada perspektif pelanggan tingkat kepuasan pelanggan juga sangat bagus terhadap kantor Perpustakaan dan Arsip Kabupaten Lumajang dengan mayoritas responden $(48,81 \%)$ mempersepsikan Baik atas pelayanan Kantor Perpustakaan dan Arsip yang diberikan selama ini kepada pelanggan. Dengan demikian, berarti pelayanan yang diberikan oleh Kantor Perpustakaan dan Arsip Lumajang terhadap pelanggan sudah baik. Untuk Perspektif Proses internal menunjukkan hasil yang baik, dibuktikan mayoritas responden yang terdiri dari atas 20 sampel dari pegawai Kantor Perpustakaan dan Arsip Kab. Lumajang menyatakan persepsi baik $(38,00 \%)$ atas kinerja Proses internal yang bekerja di internal Kantor Perpustakaan Arsip Kab. Lumajang. Kemudian pengukuran kinerja menggunakan perspektif pertumbuhan dan pembelajaran menunjukkan hasil bagus pula ditunjukkan banyaknya pegawai mengikuti pelatihan/training mencapai $46 \%$ dan rasio penggunaan teknologi terus meningkat mencapai 12 buah pada tahun 2015. Dapat disimpulkan secara keseluruhan kinerja Kantor Perpustakaan dan Arsip Kab. Lumajang dapat dikatakan baik.

\section{Saran}

Ada beberapa saran perbaikan yang bisa direkomendasikan demi perbaikan kinerja dan mutu kualitas pelayanan Kantor Perpustakaan dan Arsip Kabupaten Lumajang ke depannya, antara lain:

1. Kantor Perpustakaan dan Arsip Kabupaten Lumajang harus terus mempertahankan dan meningkatkan kinerjanya dari tahun ke tahun yang akan datang serta harus meningkatkan pelayanan kepada masyarakat dalam menjalankan kesejahteraan agar misi kemitraan dengan masyarakat dapat tercapai, dan dalam perspektif proses bisnis internal sarana dan prasarana dapat lebih ditingkatkan lagi agar menimbulkan kepuasan bekerja pada pegawai sehingga dapat meningkatkan kinerjanya. 
2. Kantor Perpustakaan dan Arsip Kabupaten Lumajang perlu meningkatkan sistem informasi dan pengadaan teknologi agar memperlancar aktivitas dalam bekerja dan juga melakukan pelatihan kepada pegawainya lebih banyak lagi.

3. Kantor Perpustakaan dan Arsip Kabupaten Lumajang harus berusaha mempertahankan hubungan baik dengan masyarakat khususnya dalam melakukan hal-hal penting dalam menumbuhkembangkan budaya dan minat membaca.

4. Untuk peneliti-peneliti berikutnya yang ingin meneliti mengenai Balanced Scorecard pada objek penelitian yang sama, disarankan untuk juga melihat beberapa tolak ukut yang telah diteliti oleh penulis sehingga pada perspektif dalam Balanced Scorecard dapat lebih dipahami dan ditingkatkan lagi untuk melihat dari target yang akan diteliti.

\section{DAFTAR PUSTAKA}

Akhmadi, Abu dan Cholid Narbuko. 2003, Metodologi Penelitian, Bumi Aksara: Jakarta.

Arikunto dan Suharsimi. 1996, Prosedur Penelitian: Suatu Pendekatan Praktik edisi ketiga, Rineka Cipta: Jakarta

Hariadi, Bambang. 2002, Akuntansi Manajemen: Suatu Sudut Pandang, BPFE: Yogyakarta.

Imelda, Nalurita. 2004, Analisa Pertanggungjawaban Kontemporer dengan Menggunakan Balanced Scorecard Sebagai Alat Pengukuran Kinerja Sektor Publik, Skripsi, Universitas Brawijaya

Jogiyanto. 2010, Metodologi Penelitian Bisnis: Salah Kaprah dan PengalamanPengalaman, BPFE: Yogyakarta.

Junaedi. 2002, Balanced Scorecard: Pengukuran Kinerja pada Pemerintahan Daerah No. 6 hal. 374-387, Kompak.

Kaplan, Robert S dan David P Norton. 2000, Balanced Scorecard: Menerapkan Strategi Menjadi Aksi Terjemahan Peter R Yosi Pasla, Erlangga: Jakarta.

Mahmudi. 2007, Manajemen Kinerja Sektor Publik Edisi Revisi, UPP STIM YKPN: Yogyakarta.

Mahsun, Mohamad. 2006, Pengukuran Kinerja Sektor Publik, BPFE: Yogyakarta.

Mardiasmo. 2004, Akuntansi Sektor Publik Edisi Kedua, Andi: Yogyakarta.

Mulyadi dan Johny Setyawan. 2001, Sistem Perencanaan dan Pengendalian Manajemen Edisi Kedua, Salemba Empat: Jakarta. 
Mulyadi. 2001, Balanced Scorecard Alat Manajemen Kontemporer untuk Melipat Ganda Kinerja Keuangan Perusahaan Edisi II Cetakan ke-1, Salemba Empat: Jakarta.

Putro, Radityo. 2009, Evaluasi Kinerja Organisasi dengan Pendekatan Balanced Scorecard pada Badan Pertanahan Kota Malang, Skripsi, Universitas Brawijaya.

Sekaran, Uma. 2003, Research Methods For Business: Metodologi Penelitian untuk Bisnis Terjemahan Kwan Men Yon 2006 Edisi Keempat jilid 2, Salemba Empat: Jakarta.

Singarimbun, Masri dan Sofian Effendi. 1995, Metode Penelitian Survei Cetakan kedua edisi revisi, LP3S: Jakarta.

Supriyono, R.A. 1990. Manajemen Strategi dan Kebijakan Bisnis Edisi 1, BPFE: Yogyakarta.

Syahrezy, Amal Rezan. 2009, Metode Kualitatif dalam Penelitian Ilmiah (online), (http://amalchips.blogspot.com). Diakses pada 3 Maret April 2016.

Umar, Husein. 2001, Metode Penelitian untuk Skripsi dan Tesis Bisnis, PT. Raja Grafindo Persada: Jakarta.

LAMPIRAN KUESIONER ANALISIS KINERJA PERSPEKTIF PELANGGAN

\begin{tabular}{|l|l|l|l|l|l|l|}
\hline No. & Keterangan & $\begin{array}{l}\text { Sangat } \\
\text { Baik (5) }\end{array}$ & Baik (4) & $\begin{array}{l}\text { Cukup } \\
\text { Baik (3) }\end{array}$ & $\begin{array}{l}\text { Kurang } \\
\text { Baik (2) }\end{array}$ & $\begin{array}{l}\text { Tidak } \\
\text { Baik (1) }\end{array}$ \\
\hline 1. & $\begin{array}{l}\text { Bagaimana } \\
\text { pelayanan yang } \\
\text { diberikan } \\
\text { Kantor } \\
\text { Perpustakaan } \\
\text { dan Arsip } \\
\text { dalam hal } \\
\text { peminjaman } \\
\text { buku dan } \\
\text { fasilitas lainnya }\end{array}$ & & & & & \\
\hline 2. & $\begin{array}{l}\text { Bagaimana } \\
\text { menurut Anda } \\
\text { prosedur yang } \\
\text { diterapkan } \\
\text { Kantor } \\
\text { Perpustakaan } \\
\text { dan Arsip } \\
\text { dalam } \\
\text { peminjaman }\end{array}$ & & & & & \\
\hline
\end{tabular}


Jurnal Cendekia Akuntansi Vol. 1 No. 1

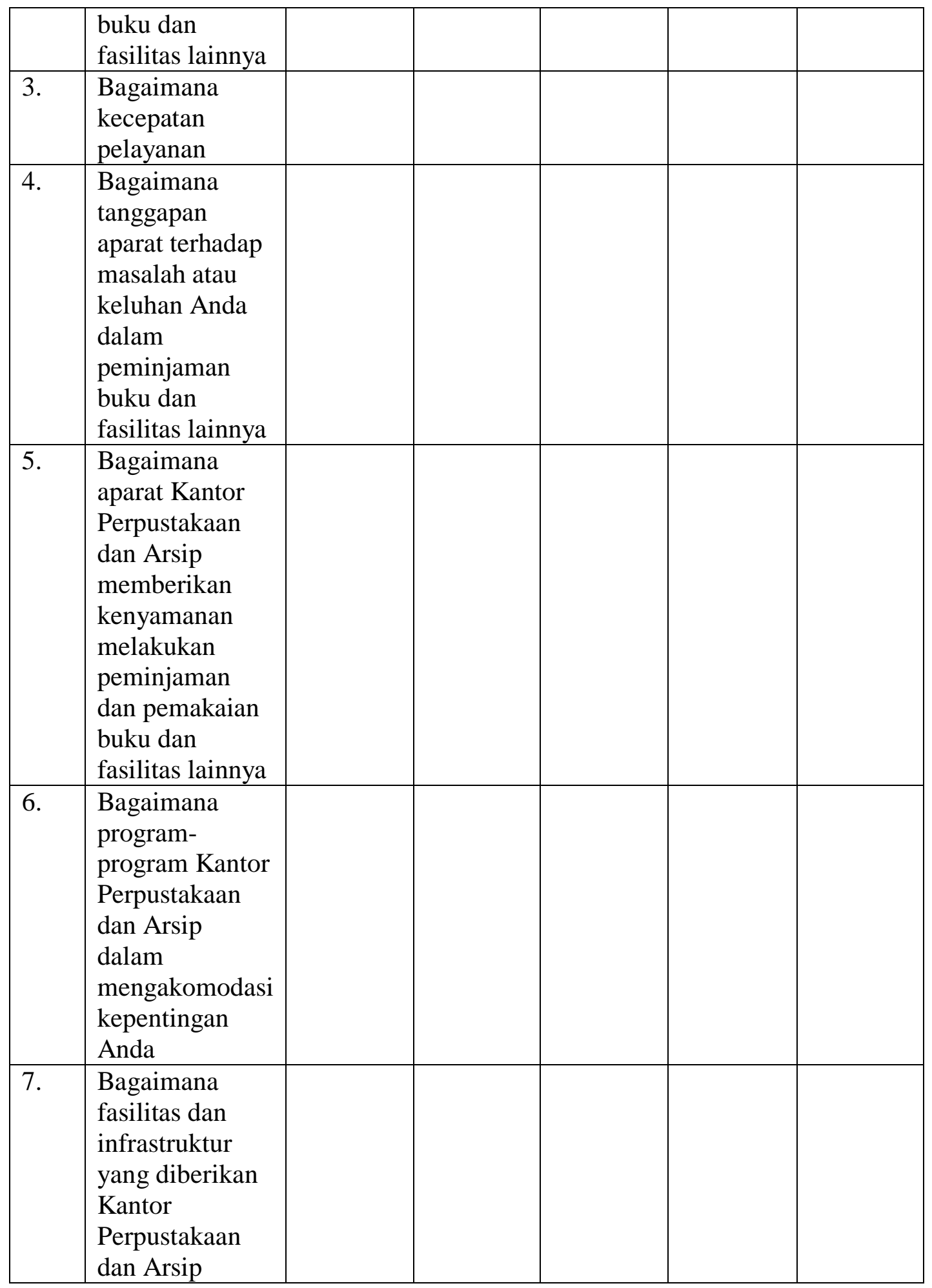


Jurnal Cendekia ARuntansi Vol. 1 No. 1

LAMPIRAN KUESIONER ANALISIS KINERJA PERSPEKTIF PROSES INTERNAL

\begin{tabular}{|c|c|c|c|c|c|c|}
\hline No. & Keterangan & $\begin{array}{l}\text { Sangat } \\
\text { Baik (5) }\end{array}$ & Baik (4) & $\begin{array}{l}\text { Cukup } \\
\text { Baik (3) }\end{array}$ & $\begin{array}{l}\text { Kurang } \\
\text { Baik (2) }\end{array}$ & $\begin{array}{l}\text { Tidak } \\
\text { Baik (1) }\end{array}$ \\
\hline 1. & $\begin{array}{l}\text { Bagaimana } \\
\text { menurut Anda } \\
\text { kedisiplinan di } \\
\text { lingkungan } \\
\text { Kantor } \\
\text { Perpustakaan } \\
\text { dan Arsip }\end{array}$ & & & & & \\
\hline 2. & $\begin{array}{l}\text { Bagaimana } \\
\text { menurut Anda } \\
\text { lingkungan } \\
\text { kerja di Kantor } \\
\text { Perpustakaan } \\
\text { dan Arsip Kab. } \\
\text { Lumajang }\end{array}$ & & & & & \\
\hline 3. & $\begin{array}{l}\text { Bagaimana } \\
\text { infrastruktur } \\
\text { dan fasilitas } \\
\text { dalam } \\
\text { menunjang } \\
\text { tugas anda }\end{array}$ & & & & & \\
\hline 4. & $\begin{array}{l}\text { Bagaimana } \\
\text { hubungan } \\
\text { pimpinan } \\
\text { dengan } \\
\text { bawahan }\end{array}$ & & & & & \\
\hline 5. & $\begin{array}{l}\text { Bagaimana } \\
\text { respon } \\
\text { pimpinan } \\
\text { terhadap } \\
\text { ide/gagasan } \\
\text { bawahan }\end{array}$ & & & & & \\
\hline 6. & $\begin{array}{l}\text { Bagaimana } \\
\text { insentif yang } \\
\text { diberikan atas } \\
\text { prestasi kerja } \\
\text { yang dihasilkan }\end{array}$ & & & & & \\
\hline 7. & $\begin{array}{l}\text { Bagaimana } \\
\text { sanksi yang } \\
\text { diberikan } \\
\text { tentang } \\
\text { kesalahan yang }\end{array}$ & & & & & \\
\hline
\end{tabular}


Jurnal Cendekia ARuntansi Vol. 1 No. 1

\begin{tabular}{|l|l|l|l|l|l|}
\hline & $\begin{array}{l}\text { dilakukan } \\
\text { bawahan }\end{array}$ & & & & \\
\hline 8. & $\begin{array}{l}\text { Bagaimana } \\
\text { kesempatan } \\
\text { yang diberikan } \\
\text { kepada pegawai } \\
\text { Kantor } \\
\text { Perpustakaan } \\
\text { dan Arsip } \\
\text { dalam } \\
\text { meningkatkan } \\
\text { kariernya }\end{array}$ & & & & \\
\hline 9. & $\begin{array}{l}\text { Bagaimana } \\
\text { motivasi yang } \\
\text { diberikan } \\
\text { pimpinan }\end{array}$ & & & & \\
\hline 10. & $\begin{array}{l}\text { Bagaimana } \\
\text { tingkat } \\
\text { kesejahteraan } \\
\text { pegawai }\end{array}$ & & & & \\
\hline
\end{tabular}

